\title{
The Rhizobium etli RpoH1 and RpoH2 sigma factors are involved in different stress responses
}

\begin{abstract}
Correspondence
Miguel A. Ramírez-Romero

mramirez@ccg.unam.mx
\end{abstract}

Received 16 June 2008

Revised 3 November 2008

Accepted 6 November 2008
Jaime M. Martínez-Salazar, ${ }^{1}$ Mario Sandoval-Calderón, ${ }^{2}$ Xianwu Guo, ${ }^{2}$ Santiago Castillo-Ramírez, ${ }^{2}$ Alma Reyes, ${ }^{2}$ Maria G. Loza, ${ }^{2}$ Javier Rivera, ${ }^{1}$ Xochitl Alvarado-Affantranger, ${ }^{3}$ Federico Sánchez, ${ }^{3}$ Víctor González, ${ }^{2}$ Guillermo Dávila ${ }^{2}$ and Miguel A. Ramírez-Romero ${ }^{2}$

\footnotetext{
${ }^{1}$ Programa de Ingeniería Genómica, Centro de Ciencias Genómicas, Universidad Nacional Autónoma de México, Apartado Postal 565-A, CP 62210 Cuernavaca, Morelos, México

${ }^{2}$ Programa de Genómica Evolutiva, Centro de Ciencias Genómicas, Universidad Nacional Autónoma de México, Apartado Postal 565-A, CP 62210 Cuernavaca, Morelos, México

${ }^{3}$ Departamento de Biología Molecular de Plantas, Instituto de Biotecnología, Universidad Nacional Autónoma de México, Apartado Postal 510-3, CP 62271 Cuernavaca, Morelos, México
}

The physiological role and transcriptional expression of Rhizobium etli sigma factors rpoH1 and $\mathrm{rpoH} 2$ are reported in this work. Both $\mathrm{rpoH} 1$ and $\mathrm{rpoH} 2$ were able to complement the temperature-sensitive phenotype of an Escherichia coli rpoH mutant. The $\mathrm{R}$. etli rpoH1 mutant was sensitive to heat shock, sodium hypochlorite and hydrogen peroxide, whereas the rpoH2 mutant was sensitive to $\mathrm{NaCl}$ and sucrose. The rpoH2 rpoH1 double mutant had increased sensitivity to heat shock and oxidative stress when compared with the $\mathrm{rpoH} 1$ single mutant. This suggests that in $R$. etli, $\mathrm{RpoH} 1$ is the main heat-shock sigma factor, but a more complete protective response could be achieved with the participation of $\mathrm{RpoH} 2$. Conversely, $\mathrm{RpoH} 2$ is involved in osmotic tolerance. In symbiosis with bean plants, the $\mathrm{R}$. etli rpoH1 and rpoH2 rpoH1 mutants still elicited nodule formation, but exhibited reduced nitrogenase activity and bacterial viability in early and late symbiosis compared with nodules produced by $\mathrm{rpoH} 2$ mutants and wildtype strains. In addition, nodules formed by $\mathrm{R}$. etli rpoH1 and $\mathrm{rpoH} 2 \mathrm{rpoH} 1$ mutants showed premature senescence. It was also determined that fix $\mathrm{Nf}$ and fix $\mathrm{Kf}$ expression was affected in $\mathrm{rpoH} 1$ mutants. Both $\mathrm{rpoH}$ genes were induced under microaerobic conditions and in the stationary growth phase, but not in response to heat shock. Analysis of the upstream region of rpoH1 revealed a $\sigma^{70}$ and a probable $\sigma^{\mathrm{E}}$ promoter, whereas in $r p o H 2$, one probable $\sigma^{\mathrm{E}}$-dependent promoter was detected. In conclusion, the two RpoH proteins operate under different stress conditions, $\mathrm{RpoH} 1$ in heat-shock and oxidative responses, and $\mathrm{RpoH} 2$ in osmotic tolerance.

\section{INTRODUCTION}

The heat-shock response in bacteria is controlled at the transcriptional level by the alternative sigma factor $\mathrm{RpoH}$ $\left(\sigma^{32}\right)$ (Arsène et al., 2000; Yura et al., 1996). Genes encoding $\mathrm{RpoH}$ have been found in the majority of the bacterial genomes sequenced to date. The RpoH sigma factors recognize a promoter sequence different from that recognized by the housekeeping $\operatorname{RpoD}\left(\sigma^{70}\right)$. A conserved region known as the 'RpoH box' characterizes the RpoH protein family; they also contain conserved sequences in regions 2.4 and 4.2 that are involved in the recognition of

Abbreviations: $\mathrm{AO}$, acridine orange; RACE, rapid amplification of cDNA ends. the -10 and -35 promoter elements (Nakahigashi et al., 1995; Wösten, 1998).

In Escherichia coli, $\mathrm{RpoH}$ controls the expression of about 91 genes (Nonaka et al., 2006). Among these are the genes encoding chaperones (GroEL, GroES, DnaK, DnaJ and GrpE) and proteases (FtsH and Lon) (El-Samad et al., 2005; Gross, 1996; Taylor et al., 1984; Yamamori \& Yura, 1980). In addition to the response to high temperatures, $\mathrm{RpoH}$ is involved in the response to oxidative stress, and has also been implicated in symbiosis and pathogenic lifestyles (Delory et al., 2006; Mitsui, et al., 2004).

Commonly, bacterial genomes contain a single $r p o H$ gene, but several $\alpha$-proteobacteria have two or three $r p o H$ homologues. Two rpoH genes have been identified in 
Brucella melitensis and Rhodobacter sphaeroides, and in the nitrogen-fixing symbionts Mesorhizobium loti, Sinorhizobium meliloti and Rhizobium etli (Galibert et al., 2001; González et al., 2006; Kaneko et al., 2000; Oke et al., 2001; Ono et al., 2001); Bradyrhizobium japonicum possesses three rpoH-like genes (Kaneko et al., 2002; Narberhaus et al., 1997). Each of the rpoH genes of Bradyrhizobium japonicum, S. meliloti, Brucella melitensis and Rhodobacter sphaeroides is able to complement, totally or partially, the temperature-sensitive phenotype of an E. coli rpoH mutant, thus suggesting that they are functionally similar to E. coli $\sigma^{32}$ (Delory et al., 2006; Green \& Donohue, 2006; Narberhaus et al., 1997; Oke et al., 2001; Ono et al., 2001). The reason for the presence of multiple $r p o H$ genes is not understood. In Bradyrhizobium japonicum, the rpoH2 gene seems to be essential, since no viable cells are recovered after knockout of this gene (Narberhaus et al., 1997), while $r p o H 1$ and $r p o H 3$ (phylogenetically related to the Rhizobiaceae $r p o H 1$ and $r p o H 2$, respectively) mutants display a phenotype indistinguishable from that of the wild-type under aerobic growth conditions or during rootnodule symbiosis; however, the gene expression and the complementation of an RpoH-deficient E. coli suggest that $r p o H 1$ and probably rpoH3 are involved in the heat-shock response (Narberhaus et al., 1997). In S. meliloti, it has been shown that only the product of $r p o H 1$ is sufficient for response to heat shock. Furthermore, an rpoH1 mutant renders the Nod+Fix - phenotype, whereas the rpoH2 rpoH1 double mutation abolishes the ability to nodulate alfalfa plants (Oke et al., 2001; Ono et al., 2001). These studies suggest that the heat-shock response in Rhizobium could overlap the response to other stimuli.

Since $R$. etli also possesses two rpoH genes, they could be expected to play a similar role in the heat-shock response to those of other bacteria. Nevertheless, in this work it was found that RpoH1 is mainly involved in heat-shock and oxidative responses, while $\mathrm{RpoH} 2$ participates in osmotic tolerance. rpoH1 inactivation affects the nitrogen fixation activity in symbiosis, and fix Nf and fixKf expression under microaerobic and aerobic conditions. Furthermore, the predicted regulatory elements in the upstream regions of $R$. etli $r p o H 1$ and $r p o H 2$ suggest that they are regulated by different sigma factors. This contribution expands previous observations and allows a more comprehensive view of the interplay between two related regulators.

\section{METHODS}

Bacterial strains and microbiological methods. The bacterial strains and plasmids used in this work are listed in Table 1. E. coli strains were grown at $37{ }^{\circ} \mathrm{C}$ in Luria-Bertani medium. R. etli strains were grown at $25{ }^{\circ} \mathrm{C}$ in peptone-yeast extract (PY) medium (Noel et al., 1984) or minimal medium (MM; $1.2 \mathrm{mM} \mathrm{K}_{2} \mathrm{HPO}_{4}, 0.8 \mathrm{mM}$ $\mathrm{MgSO}_{4}, 10 \mathrm{mM}$ succinic acid, $10 \mathrm{mM} \mathrm{NH}_{4} \mathrm{Cl}, 1.5 \mathrm{mM} \mathrm{CaCl}_{2}$ and $0.0005 \% \mathrm{FeCl}_{3}$, pH 6.8; Bravo \& Mora, 1988). Microaerobic conditions were as described by Girard et al. (2000). Antibiotics were added at the following final concentrations $\left(\mu \mathrm{g} \mathrm{ml} \mathrm{m}^{-1}\right)$ : gentamicin, 30; chloramphenicol, 25; ampicillin, 100; nalidixic acid,
20; spectinomycin, 100; kanamycin, 30; tetracycline, 10. Sucrose was used at final concentration ranging from 7.5 to $15 \%(\mathrm{w} / \mathrm{v})$. Sodium hypochlorite $(\mathrm{NaOCl})$ and hydrogen peroxide $\left(\mathrm{H}_{2} \mathrm{O}_{2}\right)$ (Sigma) were added at final concentrations ranging from 0.4 to $0.6 \%$ and from 2 to $80 \mathrm{mM}$, respectively.

To determine the survival rates with $\mathrm{NaOCl}$ and $\mathrm{H}_{2} \mathrm{O}_{2}$, the $R$. etli strains were grown in PY medium at $25{ }^{\circ} \mathrm{C}$ and agitated at 200 r.p.m. Aliquots were taken at 12 and $36 \mathrm{~h}$ post-inoculation $\left(\mathrm{OD}_{600} \sim 0.4\right.$ and $\sim 1.4$, respectively) and incubated with different concentrations of $\mathrm{NaOCl}$ or $\mathrm{H}_{2} \mathrm{O}_{2}$ for $45 \mathrm{~min}$ at $25{ }^{\circ} \mathrm{C}$. After treatment, samples were diluted in $10 \mathrm{mM} \mathrm{MgSO}_{4}, 20 \mathrm{mM}$ Tween 40, and plated in PY medium.

Conjugative mobilization of plasmids from E. coli to Rhizobium was done by triparental mating using pRK2013 plasmid as a helper (Simon et al., 1983).

DNA and RNA isolation and manipulation. Genomic DNA was isolated using the GenomicPrep cells and tissue DNA isolation kit (Amersham Biosciences) following the manufacturer's instructions. Plasmid DNA was isolated as described by Sambrook et al. (1989). Restriction enzymes and T4 DNA ligase were used as specified by the manufacturer (Invitrogen). $P f u$ and Taq DNA polymerase (Altaenzymes) were used for PCRs. RNAs were isolated using the High Pure RNA Isolation kit (Roche). All the primers used are listed in Table 2 (purchased from Unidad de Biosíntesis, Instituto de Biotecnología, Universidad Nacional Autónoma de México).

Plasmid construction. The $1.65 \mathrm{~kb}$ R. etli rpoH1 and $2.02 \mathrm{~kb}$ R. etli $r p o H 2$ regions were amplified by PCR from the CE3 strain and cloned into the XbaI site of the $\mathrm{pK} 18$ mobsacB plasmid (Schafer et al., 1994) to give pJMS16 and pJMS17, respectively. pJMS18 is a pJMS16 derivative harbouring the $\mathrm{R}$. etli rpoH1 gene interrupted at the BamHI site (at codon 250) by insertion of $2.3 \mathrm{~kb} \mathrm{BamHI}$ loxPSp interposon from pJMS2 (Martínez-Salazar \& Romero, 2000). pJMS19 is a pJMS17 derivative harbouring the $\mathrm{R}$. etli rpoH2 gene interrupted at the BclI site (at codon 10) by insertion of $2.3 \mathrm{~kb} B a m \mathrm{HI}$ loxPSp interposon from pJMS2. For both $\mathrm{R}$. etli rpoH1-uidA and rpoH2uidA transcriptional fusions, pBBMCS53 (Girard et al., 2000) derivatives carrying the native promoters of $\mathrm{R}$. etli rpoH1 and rpoH2 were constructed. A 477 bp PCR fragment containing 217 bp upstream and $260 \mathrm{bp}$ of the rpoH1 gene was cloned into the XbaI and SalI sites of pBBMCS53 to give pGUSprpoH1. For the rpoH2 promoter, a 657 bp fragment generated by PCR that carried 548 bp upstream and 109 bp of the rpoH2 gene was cloned into the XbaI and SalI sites of pBBMCS53 to give pGUSprpoH2. A 936 bp PCR fragment containing the $R$. etli rpoH1 gene from CE3 was cloned into the PstI and EcoRI sites of pRK415 (Keen et al., 1988) to give pRK415ReH1. For R. etli rpoH2, an 894 bp fragment generated by PCR that carried the gene, was cloned into the BamHI and EcoRI sites of pRK415 to give pRK415ReH2. An 885 bp PCR fragment containing the E. coli $r p o H$ gene from MC4100 was cloned into the BamHI and $E c o$ RI sites of pRK415 to give pRK415EcH. The three $r p o H$ genes were cloned downstream of the lac promoter present in pRK415, and no IPTG was used due to high basal expression in this vector.

Construction of $\boldsymbol{R}$. etli mutants. The $\mathrm{R}$. etli rpoH1 and rpoH2 mutants were obtained by gene replacement of the wild-type allele by rpoH1:: loxPSp (pJMS18) or rpoH2::loxPSp (pJMS19) alleles, respectively. For this purpose, the corresponding plasmid was mobilized from E. coli to $R$. etli by triparental mating, and double recombinants were screened by $\mathrm{Sp}^{\mathrm{r}} \mathrm{Sac}^{\mathrm{r}} \mathrm{Km}^{\mathrm{s}}$ phenotype. The $r p o H 2$ rpoH1 double mutant was generated by a two-step procedure. In the first step, the $S p^{r}$ marker was excised from the loxPSp interposon in strain CFNXH2 (rpoH2::loxPSp) by using the loxP-specific Cre recombinase located in pJMS8 (J. M. Martínez-Salazar and others, unpublished data). Losses of the $\mathrm{Sp}^{\mathrm{r}}$ marker and pJMS8 were screened 
Table 1. Strains and plasmids used in this work

\begin{tabular}{|c|c|c|}
\hline Strain or plasmid & Relevant characteristics & Source or reference \\
\hline \multicolumn{3}{|l|}{ R. etli strains } \\
\hline CE3 & Streptomycin-resistant, nodulates $P$. vulgaris & Noel et al. (1984) \\
\hline CFNXH1 & CE3 derivative, rpoH1: : loxPSp & This work \\
\hline CFNXH2 & CE3 derivative, $r p o H 2::$ loxPSp & This work \\
\hline CFNXH2lox & CEXH2 derivative, $\mathrm{Sp}$ deletion, rpoH2: : loxP & This work \\
\hline CFNXH2H1 & CEXH2lox derivative, rpoH1:: loxPSp & This work \\
\hline \multicolumn{3}{|l|}{ E. coli strains } \\
\hline $\mathrm{DH} 5 \alpha$ & Host strain for plasmids & Hanahan (1983) \\
\hline BW21038 & uidA derivative & Metcalf \& Wanner (1993) \\
\hline S17.1 & Host strain used for conjugation & Simon et al. (1983) \\
\hline JMH1025 & MC4100 $\Delta r p o H::$ kan derivative & Díaz-Acosta et al. (2006) \\
\hline \multicolumn{3}{|l|}{ Plasmids } \\
\hline pBBMCS53 & $\mathrm{Gm}^{\mathrm{r}}$, replicable in $R$. etli, carrying a promoterless $\beta$-glucuronidase gene & Girard et al. (2000) \\
\hline pRK2013 & Conjugation helper plasmid, $\mathrm{Km}^{\mathrm{r}}$ & Ditta et al. (1980) \\
\hline pRK415 & pRK290 derivative, $\mathrm{Tc}^{\mathrm{r}}$ & Keen et al. (1988) \\
\hline pK18mobsacB & $\mathrm{Km}^{\mathrm{r}}$, used for gene replacement & Schafer et al. (1994) \\
\hline pJMS2 & Plasmid harbouring the loxPSp interposon & Martínez-Salazar \& Romero (2000) \\
\hline pJMS8 & pRK7813 derivative, harbouring cre gene & $\begin{array}{l}\text { J. M. Martínez-Salazar and others, } \\
\text { unpublished data }\end{array}$ \\
\hline pLG1 & pBBMCS53 derivative carrying the $R$. etli fixKf-uidA transcriptional fusion & Girard et al. (2000) \\
\hline pLG2 & pBBMCS53 derivative carrying the $R$. etli fixNf-uidA transcriptional fusion & Girard et al. (2000) \\
\hline pLG4 & pBBMCS53 derivative carrying the $R$. etli fixNd-uidA transcriptional fusion & Girard et al. (2000) \\
\hline pGUSprpoH1 & pBBMCS53 derivative carrying the $\mathrm{R}$. etli $r p o H 1-u i d A$ transcriptional fusion & This work \\
\hline pGUSprpoH2 & pBBMCS53 derivative carrying the $\mathrm{R}$. etli rpoH2-uidA transcriptional fusion & This work \\
\hline pRK415ReH1 & pRK415 derivative carrying a 936 bp fragment with the $\mathrm{R}$. etli $r p o H 1$ gene & This work \\
\hline pRK415ReH2 & pRK415 derivative carrying an 894 bp fragment with the $\mathrm{R}$. etli rpoH2 gene & This work \\
\hline pRK415EcH & pRK415 derivative carrying an 885 bp fragment with the E. coli rpoH gene & This work \\
\hline pJMS16 & $\begin{array}{l}\text { pK18mobsacB derivative carrying a } 1.65 \mathrm{~kb} \text { fragment containing the } R \text {. etli } \\
r p o H 1 \text { gene }\end{array}$ & This work \\
\hline pJMS17 & $\begin{array}{l}\text { pK18mobsacB derivative carrying a } 1.65 \mathrm{~kb} \text { fragment containing the } R . \text { etli } \\
\text { rpoH2 gene }\end{array}$ & This work \\
\hline pJMS18 & $\begin{array}{l}\text { pJMS16 derivative carrying the } R \text {. etli rpoH1 gene interrupted at the BamHI site } \\
\text { (at codon 250) by insertion of } 2.3 \mathrm{~kb} \mathrm{BamHI} \text { loxPSp }\end{array}$ & This work \\
\hline pJMS19 & $\begin{array}{l}\text { pJMS17 derivative carrying the } R \text {. etli } r p o H 2 \text { gene interrupted at the } B c l \text { site } \\
\text { (at codon 10) by insertion of } 2.3 \mathrm{~kb} B a m \mathrm{HI} \text { loxPSp }\end{array}$ & This work \\
\hline
\end{tabular}

by $\mathrm{Sp}^{\mathrm{s}} \mathrm{Tc}^{\mathrm{s}}$ phenotype. In a second step, the rpoH1:: loxPSp (pJMS18) allele was introduced into the CFNXH2lox strain $(r p o H 2:: \operatorname{loxP})$ by a marker-exchange procedure.

Nodulation, nitrogen fixation determination and bacterial viability on nodules. Phaseolus vulgaris 'Negro Jamapa' seeds were surface-sterilized and germinated on sterile trays containing sterile vermiculite. Three-day-old seedlings were transferred to 11 plastic pots containing sterile vermiculite and inoculated with the desired $R$. etli strain. Plants were kept in a culture room at $25{ }^{\circ} \mathrm{C}$ under a $12 \mathrm{~h}$ light/dark period, and watered with a nitrogen-free nutrient solution (Fahraeus, 1957). Acetylene reduction assays for nitrogenase activity were carried out as described by Romero et al. (1988). Nodules were surface-sterilized with $\mathrm{NaOCl} 2.0 \%(\mathrm{w} / \mathrm{v})$ and disrupted with $10 \mathrm{mM}$ $\mathrm{MgSO}_{4}, 20 \mathrm{mM}$ Tween 40, and dilution series were plated on PY medium.

Fluorescence microscopy by acridine orange (AO)/ethidium bromide staining. Nodule cell death was studied morphologically by using fluorescent DNA-binding dyes. AO stains DNA bright green, allowing visualization of the nuclear chromatin (Vento et al., 1998). Nodules were disrupted in stabilization solution (50 mM PIPES,
pH 6.9, 5 mM EGTA, 2 mM $\mathrm{MgSO}_{4}, 100 \mathrm{mM} m$-maleimidobenzoyl$N$-hydroxysuccinimide ester and $0.1 \%$ Triton X-100), stained with $\mathrm{AO} /$ ethidium bromide solution $\left(10 \mu \mathrm{g} \mathrm{AO} \mathrm{ml} \mathrm{m}^{-1}, 10 \mu \mathrm{g}\right.$ ethidium bromide $\mathrm{ml}^{-1}$, in PBS), mixed gently, and then examined through a Zeiss LSM 510 Meta confocal microscope attached to an Axiovert $200 \mathrm{M}$ inverted microscope, using an argon laser and an HFT UV $488 / 542 / 633 \mathrm{~nm}$ dual dichroic excitation mirror with an LP $505 \mathrm{~nm}$ emission filter for detection.

$\boldsymbol{\beta}$-Glucuronidase activity measurements. The cultures were grown overnight in the presence of the appropriate antibiotic selection, and then diluted in fresh PY medium or MM to $\mathrm{OD}_{540} 0.01$ and grown to exponential and stationary phases (about 12 and $24 \mathrm{~h}$, respectively). Quantitative $\beta$-glucuronidase assays were performed with 4-nitrophenyl $\beta$-D-glucuronide substrate as described by Girard et al. (2000). Nodules were isolated and stained for $\beta$-glucuronidase activity using $\mathrm{X}$-gluc (5-bromo-4-chloro-indolyl glucuronide) as substrate, as described by Pichon et al. (1992).

Transcription start site determination. Transcription start sites were mapped by means of $5^{\prime}$ rapid amplification of cDNA ends (RACE) kit version 2.0 (Invitrogen), as previously described 
Table 2. Primers used in this work

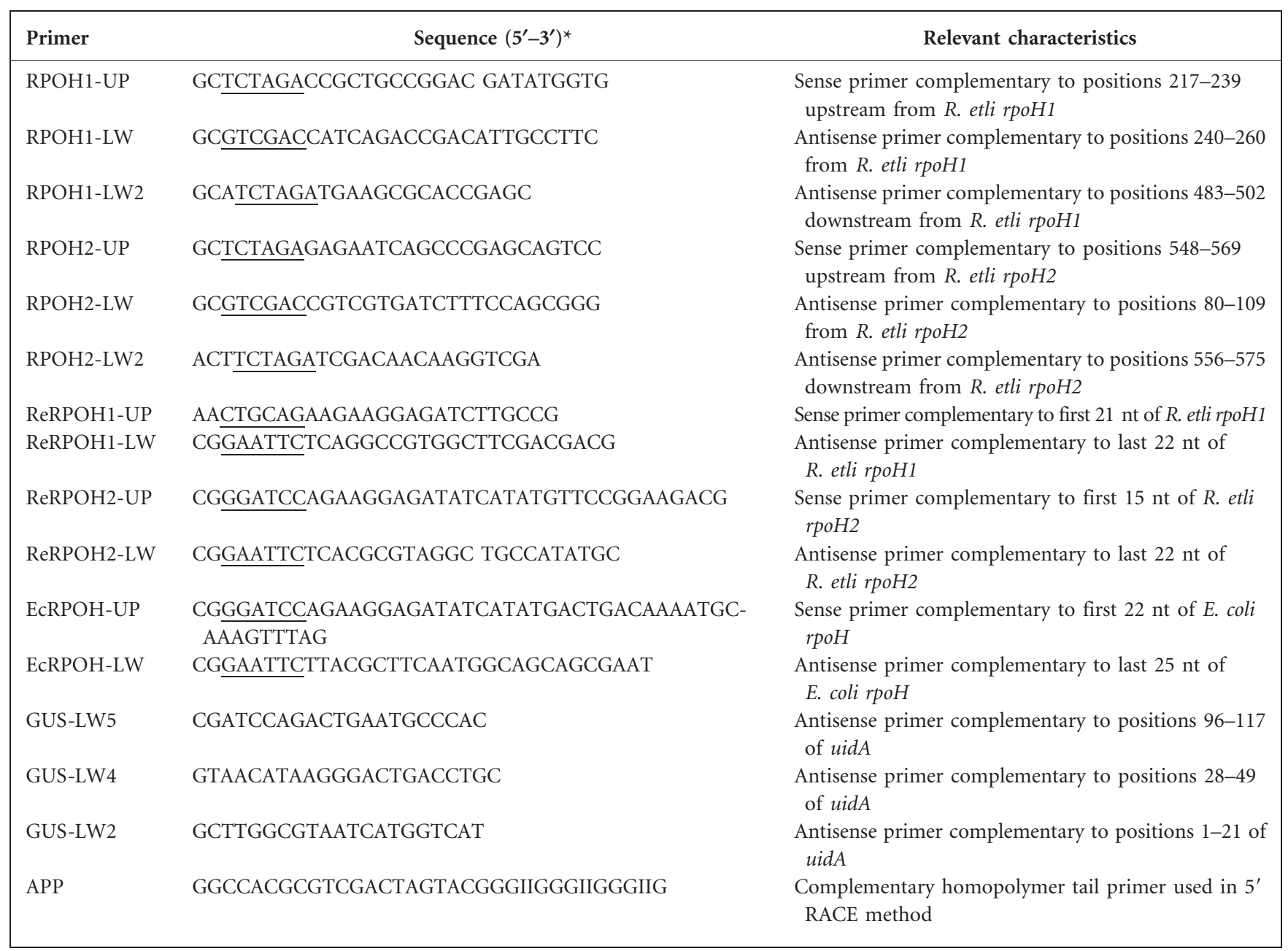

${ }^{\star}$ Underlining denotes restriction sites.

(Ramírez-Romero et al., 2006). The R. etli RNA was isolated from strains containing plasmid-borne transcriptional pGUSprpoH1 or pGUSprpoH2. Single-chain DNA (scDNA) was synthesized using the primer GUS-LW5 (Table 2). PCR amplification was accomplished by using a second antisense primer GUS-LW4 and a complementary homopolymer tail primer AAP (Table 2). When secondary bands were obtained, an additional PCR was done using AAP primer and antisense primer GUS-LW2 (Table 2). The PCR products were sequenced in an automatic 3730xl DNA sequencer (Applied Biosystems). The DNA sequencing reactions were performed using appropriate primers and BigDye Terminator kit version 3.1.

\section{RESULTS}

\section{$R$. etli rpoH genes complement the heat-sensitive phenotype of an E. coli rpoH mutant}

To determine whether the $R$. etli rpoH genes can sustain a heat-shock response, they were expressed under lac promoter control in E. coli JMH1025. This strain is unable to respond to an increase in temperature due to the deletion of the rpoH gene and cannot grow at $42{ }^{\circ} \mathrm{C}$. When plasmids containing $\mathrm{R}$. etli rpoH1 or $r p o H 2$ were expressed in E. coli JMH1025, the strain was able to grow at $42{ }^{\circ} \mathrm{C}$ (data not shown). After heat shock $\left(42{ }^{\circ} \mathrm{C}\right.$ for $\left.30 \mathrm{~min}\right)$, the survival fraction (ratio of viable cells at $42{ }^{\circ} \mathrm{C}$ with respect to $30{ }^{\circ} \mathrm{C}$ ) was about $0.08 \pm 0.08$ when $\mathrm{RpoH} 1$ was present and $0.18 \pm 0.14$ for $\mathrm{RpoH} 2$. Even though these values were lower than those exhibited by E. coli JM1025 with its own $r p o H$ gene on the plasmid (survival fraction of $0.36 \pm 0.31$ ), they were three orders of magnitude higher than in absence of any rpoH gene. These results show that both rpoH1 and rpoH2 are able to complement the E. coli rpoH mutant under heat-shock stress.

\section{rpoH1 encodes the principal heat-shock sigma factor of $R$. etli}

Considering that both $\mathrm{R}$. etli rpoH genes partially complement the E. coli rpoH mutant, it is likely that their protein products mediate the heat-shock response in the cellular context of $R$. etli. To test this hypothesis, single $(r p o H 1$ and rpoH2) and double $(r p o H 2 ~ r p o H 1)$ mutants 
were constructed by gene replacement at $25{ }^{\circ} \mathrm{C}$ to avoid secondary mutations (see Methods). Both single and double mutants were viable at $30{ }^{\circ} \mathrm{C}$, the normal growth temperature of $R$. etli, and although we observed that $r p o H 1$ and $r p o H 2 r p o H 1$ mutants grew slightly slower than the wild-type, no significant differences were determined. Therefore, the $R$. etli strains were grown at $25{ }^{\circ} \mathrm{C}$ in the subsequent experiments. Under heat-shock conditions (temperature shift to $42{ }^{\circ} \mathrm{C}$ for $30 \mathrm{~min}$ ), the survival fraction of the rpoH1 mutant was reduced to $3.7 \pm 2.2 \times 10^{-3}$ (a 270 -fold reduction with respect to the wild type), whereas the $\mathrm{rpoH} 2$ mutant remained unaffected (survival fraction $0.93 \pm 0.07$ ). Significantly, the $r p o H 2$ rpoH1 mutation decreased the survival fraction to $1.9 \pm 3 \times 10^{-4}$ (a 5200 -fold reduction with respect to the wild-type; a 19-fold reduction with respect to the rpoH1 mutant) after heat shock. These results indicate that $\mathrm{RpoH} 1$ has an important role in the heat-shock response, whereas $\mathrm{RpoH} 2$ has a minor role in this type of stress.

\section{R. etli rpoH1 and rpoH2 genes are involved in the oxidative stress response}

In addition to its known role in protection against heat stress, $\mathrm{RpoH}$ has been implicated in the oxidative stress response (Bang et al., 2005; Díaz-Acosta et al., 2006). Rhizobium, like some pathogens, induces an oxidative burst when it invades plant roots (Santos et al., 2001). In its freeliving form, endogenous oxidative molecules are generated as by-products of aerobic metabolism. Therefore, the $R$. etli $r p o H$ mutants were tested for sensitivity to $\mathrm{H}_{2} \mathrm{O}_{2}$ and $\mathrm{NaOCl}$ in exponential and stationary growth phases. The $R$. etli wild-type strain was more resistant to $\mathrm{H}_{2} \mathrm{O}_{2}$ in stationary phase $(80 \mathrm{mM})$ than in the exponential growth phase ( $8 \mathrm{mM}$ ) (Fig. la, c). Under the same conditions, the $\mathrm{rpoH} 2$ rpoH1 double mutant was shown to be sensitive to $8 \mathrm{mM}$ $\mathrm{H}_{2} \mathrm{O}_{2}$ in the exponential growth phase (Fig. 1a), and also displayed a clear hypersensitivity to $80 \mathrm{mM} \mathrm{H}_{2} \mathrm{O}_{2}$ during the stationary phase (Fig. 1c). The $\mathrm{rpoH}$ single mutants did not generate significant differences in response to $\mathrm{H}_{2} \mathrm{O}_{2}$ in either the exponential or the stationary growth phase.

In the presence of $0.6 \% \mathrm{NaOCl}$, the double mutant displayed a 100 -fold viability reduction with respect to the wild-type in exponential growth phase (Fig. 1b), and a 10000 -fold reduction in stationary phase (Fig. 1d). The rpoH1 single mutant was sensitive (1000-fold viability reduction with respect to wild-type) only in the stationary phase, whereas the $\mathrm{rpoH} 2$ mutant did not show any appreciable phenotype under the conditions tested. These results indicate that both $\mathrm{R}$. etli $\mathrm{RpoH} 1$ and $\mathrm{RpoH} 2$ are involved in resistance to oxidative stress generated by $\mathrm{H}_{2} \mathrm{O}_{2}$ and $\mathrm{NaOCl}$.

\section{RpoH2 is involved in the osmotic stress response}

In the rhizosphere, bacteria are exposed to the detrimental effects of changes in salinity and osmolarity. Salinity affects the survival of Rhizobium in the soil, and may also inhibit

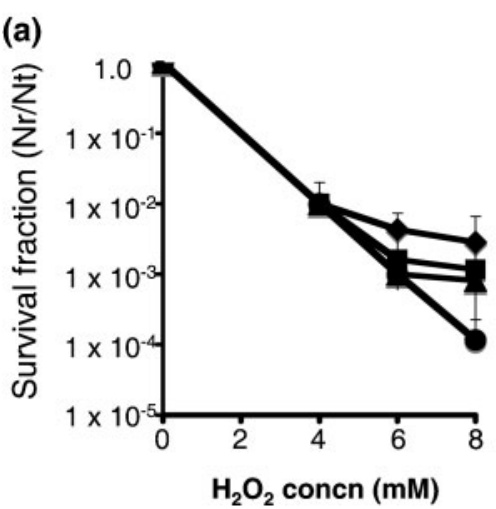

(c)

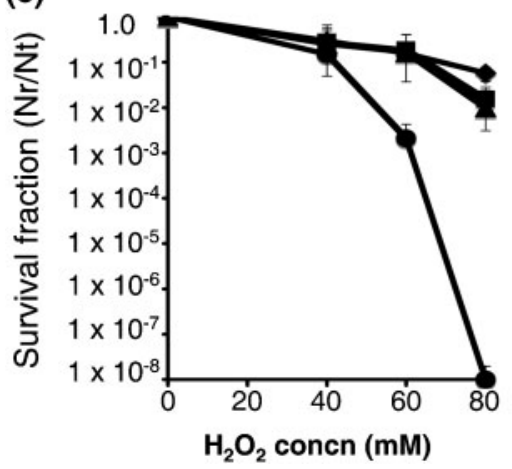

(b)

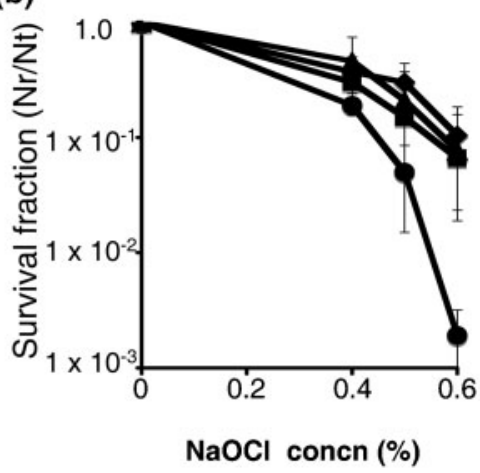

(d)

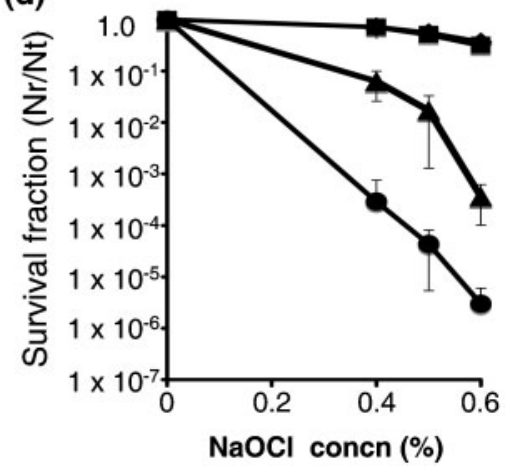

Fig. 1. Sensitivity of $\mathrm{RpoH}$-deficient $R$. etli strains to $\mathrm{H}_{2} \mathrm{O}_{2}$ and $\mathrm{NaOCl}$. Exponential $(\mathrm{a}, \mathrm{b})$ and stationary $(c, d)$ cultures were incubated for 45 min with $\mathrm{H}_{2} \mathrm{O}_{2}(\mathrm{a}, \mathrm{c})$ or $\mathrm{NaOCl}(\mathrm{b}, \mathrm{d})$. The survival fraction is the number of viable cells after treatment $(\mathrm{Nr})$ divided by the number of viable cells without treatment $(\mathrm{Nt})$. The data are the mean of at least three independent experiments. CE3 strain, ; CFNXH2 (rpoH2 : : loxPSp), $\mathbf{\square}$; CFNXH1 (rpoH1::loxPSp), $\mathbf{\Delta}$ CFNXH2H1 (rpoH2 : : loxP-rpoH1 : : loxPSp), 
the initial steps of symbiosis (root colonization, infection and nodule development) and nitrogen fixation (Nogales et al., 2002; Zahran, 1999). Moreover, Rhizobium must adapt to osmotic changes during the infection process and in nodules (Botsford \& Lewis, 1990). For that reason, the $r p o H$ mutants were tested for survival in $\mathrm{NaCl}$ and sucrose in early stationary growth phase. The $\mathrm{R}$. etli wild-type and $r p o H 1$ mutant were resistant to both $80 \mathrm{mM} \mathrm{NaCl}$ and $15 \%$ sucrose, whereas the rpoH2 mutant showed a significantly lower viability with respect to the wild-type strain in both $80 \mathrm{mM} \mathrm{NaCl}$ and $15 \%$ sucrose (1000-fold; Fig. 2). The rpoH2 rpoH1 double mutant was as sensitive to $\mathrm{NaCl}$ and sucrose as the rpoH2 mutant (Fig. 2). These results suggest that $R$. etli $\mathrm{RpoH} 2$ has a role in tolerance to the osmotic stress generated by $\mathrm{NaCl}$ and sucrose, unlike $\mathrm{RpoH} 1$, which does not display any detectable participation.

\section{Role of rpoH genes in symbiosis}

Earlier studies of the heat-shock response in S. meliloti have indicated that $\mathrm{RpoH}$ plays a role in symbiosis (Mitsui et al., 2004; Oke et al., 2001; Ono et al., 2001). To investigate whether the $\mathrm{R}$. etli rpoH genes participate in symbiosis, we tested the capability of the $\mathrm{R}$. etli rpoH mutants to establish nitrogen-fixing nodules in bean plants. In these experiments, white nodules (associated with the absence of leghaemoglobin) in the rpoH1 and $r p o H 2 r p o H 1$ mutants were obtained, and the number of nodules was similar to that of wild-type strains. These results were obtained in several experiments with low variability, suggesting that the nodules induced by the mutants could not contain suppressor mutations (data not shown).

Twenty-one days after inoculation, the rpoH1 and $r p o H 2$ rpoH1 mutants were able to nodulate but were defective in nitrogen fixation (Fig. 3). The $r p o H 2$ strain was able to form nodules and had a specific nitrogen fixation activity $(21.91 \pm 1.40)$ comparable to that of the wild-type strain $(22.22 \pm 4.65)$. The rpoH2 rpoH1 mutant had nitrogen fixation activity 20-fold lower than that of the rpoH1 mutant $(0.05 \pm 0.08$ and $1.02 \pm 0.05$, respectively; Fig. 3$)$, suggesting that the two genes act synergistically during symbiosis. Lack of nitrogen fixation capacity in the $r p o H 1$ mutant could be due to: (1) alteration of nif or fix gene expression; (2) modification of nodule development; and/ or (3) low bacterial viability inside the nodule.

A low number of viable bacteria was recovered from nodules formed by rpoH1 and rpoH2 rpoH1 mutants in early and late symbiosis, and after 26 days bacterial viability in nodules generated by the $\mathrm{rpoH} 2 \mathrm{rpoH} 1$ mutant was drastically affected. Conversely, nodules formed by the rpoH2 mutant showed a viable cell number similar to that of the wild-type strain. Microscopy analysis showed that nodules produced by rpoH1 (Fig. 4c) and rpoH2 rpoH1 (Fig. 4d) mutants were prematurely senescent compared with the nodules generated by the $\mathrm{rpoH} 2$ mutant (Fig. 4b) and wild-type (Fig. 4a) strains. These results suggest that RpoH1 plays a role in bacterial survival inside the nodule.

If RpoH1 takes part in nitrogen fixation, it might be possible to find sequences similar to $\mathrm{RpoH}$ promoters upstream of some nif or fix genes. As a matter of fact, we found sequences that resemble the E. coli $\mathrm{RpoH}$ consensus promoter upstream of the translation start of fix Nd, fix Nf (cytochrome oxidase genes located in $\mathrm{p} 42 \mathrm{~d}$ and $\mathrm{p} 42 \mathrm{f}$ plasmids, respectively) and fixKf (an FNR transcriptional regulator located in p42f plasmid) (G. Lopez-Leal and others, unpublished data). To test whether $\mathrm{RpoH}$ family members are able to control the expression of these genes, plasmids containing fixNd-uidA, fixKf-uidA or fixNf-uidA transcriptional fusions were transferred into the wild-type, $r p o H 1$ and $r p o H 2 r p o H 1$ strains. Since fix gene expression is controlled by oxygen tension (Fischer, 1994; Girard et al., 2000), the activity of the fusions under aerobic and microaerobic (1\% oxygen) conditions was determined. As expected, in the wild-type strain, the three fusions had increased transcription in microaerobiosis with respect to aerobiosis (Fig. 5). In microaerobiosis, the expression of the fixNf and fixKf fusions was reduced to $50 \%$ in both the rpoH1 and the rpoH2 rpoH1 mutants compared with wildtype, whereas the fix $N d$ fusion maintained expression levels similar to those of the wild-type (Fig. 5b). Despite the reduced expression of the fusions under aerobic conditions, the absence of $\mathrm{RpoH}$ still produced an observable phenotype. fixNd, fixNf and fixKf gene expression was reduced to about $60 \%$ in the rpoH1 mutant, whereas no activity was found in the rpoH2 rpoH1 mutant (Fig. 5a). These results suggest that RpoH1 has either a direct or an indirect influence on the regulation of fixNf and fixKf genes under aerobic and microaerobic conditions.

\section{Gene expression of the $R$. etli rpoH genes}

Given the above results, determination of the growth conditions under which rpoH1 and $r p o H 2$ are expressed was desirable. This was achieved by measuring the $\beta$ glucuronidase activity using plasmids containing transcriptional fusions of rpoH1-uidA and rpoH2-uidA. Maximum expression of rpoH1 and $r p o H 2$ was obtained in the

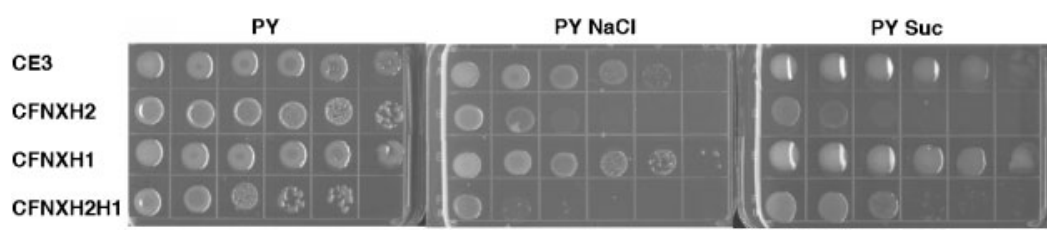

Fig. 2. Saline and osmotic tolerance of $R$. etli $r p o H$ mutants. Serial dilutions of cells in early stationary growth phase were plated on $\mathrm{PY}$ (control), or PY containing $80 \mathrm{mM} \mathrm{NaCl}$ or $15 \%$ sucrose. 


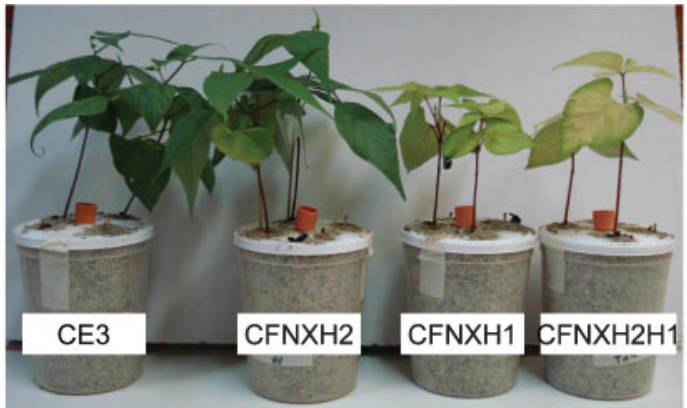

$\begin{array}{lllcc}\text { S.A. } & 22.22 & 21.91 & 1.02 & 0.05 \\ \text { (SD) } & (4.65) & (1.40) & (0.05) & (0.08)\end{array}$

Fig. 3. Role of $R$. etli rpoH genes in nodulation and nitrogen fixation. Plants growing for 21 days after inoculation with the strains are shown. Ethylene reduction was used to determine nitrogen fixation specific activity (S.A.; micromoles of ethylene per milligram of nodules per hour). The data are the mean of at least three independent experiments.

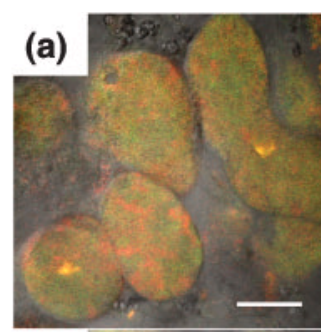

(c)
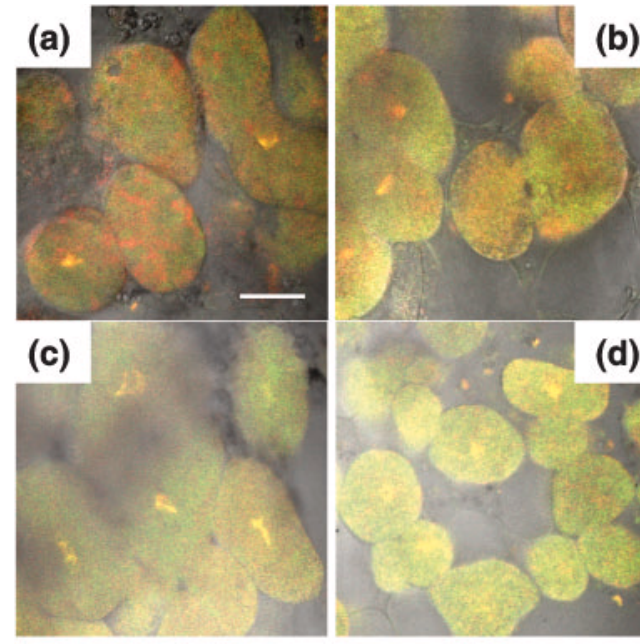

(d)

(e)

\begin{tabular}{|lcc|}
\hline Strain & \multicolumn{2}{c|}{$\begin{array}{c}\text { Median of bacterial viable cells } \\
\text { inside the nodule at }\end{array}$} \\
\cline { 2 - 3 } & $\mathbf{1 8}$ days & $\mathbf{2 6}$ days \\
\hline CE3 & ${ }^{\star} 3.0 \times 10^{8}$ & ${ }^{\star} 3.4 \times 10^{8}$ \\
CFNXH2 & $2.8 \times 10^{8}$ & $3.0 \times 10^{8}$ \\
CFNXH1 & ${ }^{\star} 3.6 \times 10^{7}$ & ${ }^{*} 5.2 \times 10^{7}$ \\
CFNXH2H1 & ${ }^{*} 1.2 \times 10^{7}$ & ${ }^{*} 6.0 \times 10^{6}$ \\
\hline
\end{tabular}

Fig. 4. Viability of nodule cells. Nodules of 18-day-old $P$. vulgaris colonized with (a) CE3, (b) CFNXH2 (rpoH2 : : loxPSp), (c) CFNXH1 (rpoH1 : : loxPSp) and (d) CFNXH2H1 (rpoH2 : : lox-rpoH1 : : loxPSp) were stained with $\mathrm{AO} /$ ethidium bromide and observed by fluorescence microscopy (×63 magnification). Bar, $50 \mu \mathrm{m}$. (e) Numbers of viable bacteria inside nodules for wild-type and $R$. etli $r p o H$ mutants. The data are the median of 10 nodules from at least three independent experiments. The asterisks indicate statistically significant differences according to the Kruskal-Wallis test at the $95 \%$ confidence level.
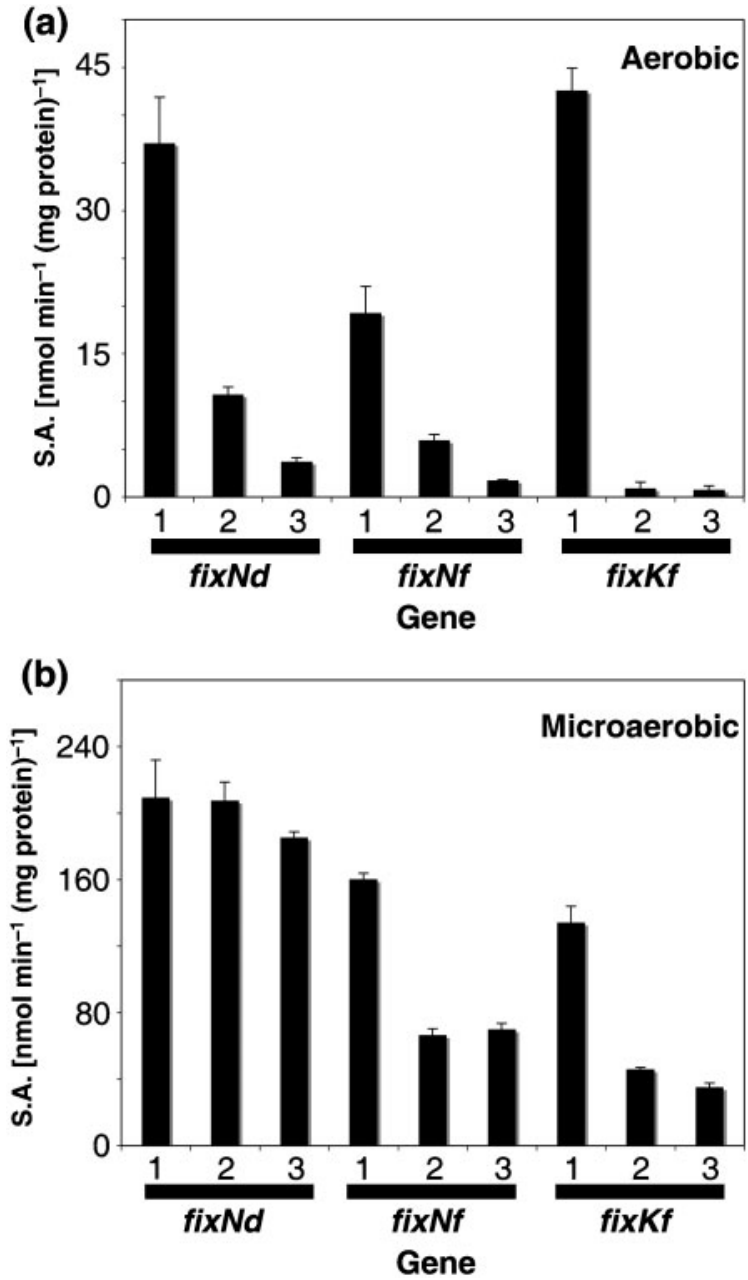

Fig. 5. $\mathrm{R}$. etli $r p o H$ genes regulate the expression of fix Kf, fix $\mathrm{Nd}$ and fixNf genes. CE3 (1), CFNXH1 (2; rpoH1::loxPSp) and CFNXH2H1 (3; rpoH2:: lox-rpoH1:: loxPSp) strains harbouring the plasmids pLG4 (fix $N d)$, pLG2 (fixNf) and pLG1 (fixKf) in exponential-growth cultures under aerobic (a) and microaerobic (b) conditions were used to determinate $\beta$-glucuronidase specific activity [S.A.; nmol $\mathrm{min}^{-1}$ (mg protein) ${ }^{-1}$ ]. The data are the mean of at least three independent experiments.

stationary growth phase in both rich and minimal media (Fig. 6). Moreover, the rpoH1 fusion had a higher level of expression in PY than in MM, whereas the rpoH2 fusion had similar expression levels in both media. In addition, a twofold increase in expression of $\mathrm{rpoH} 1$ and $\mathrm{rpoH}_{2}$ in minimal medium at low oxygen concentrations was observed (Fig. 6b, c). In contrast, a temperature shift from 25 to $42{ }^{\circ} \mathrm{C}$ for a period ranging from $45 \mathrm{~min}$ to $24 \mathrm{~h}$ did not have any effect on either rpoH1 or rpoH2 expression (Fig. 6, data not shown). As a whole, these results suggest that $\mathrm{rpoH} 1$ and $\mathrm{rpoH} 2$ are transcriptionally upregulated in the microaerobic stationary phase, even though rpoH1 always had higher expression levels than rpoH2. In agreement with the effect of the $r p o H 1$ mutation on the 

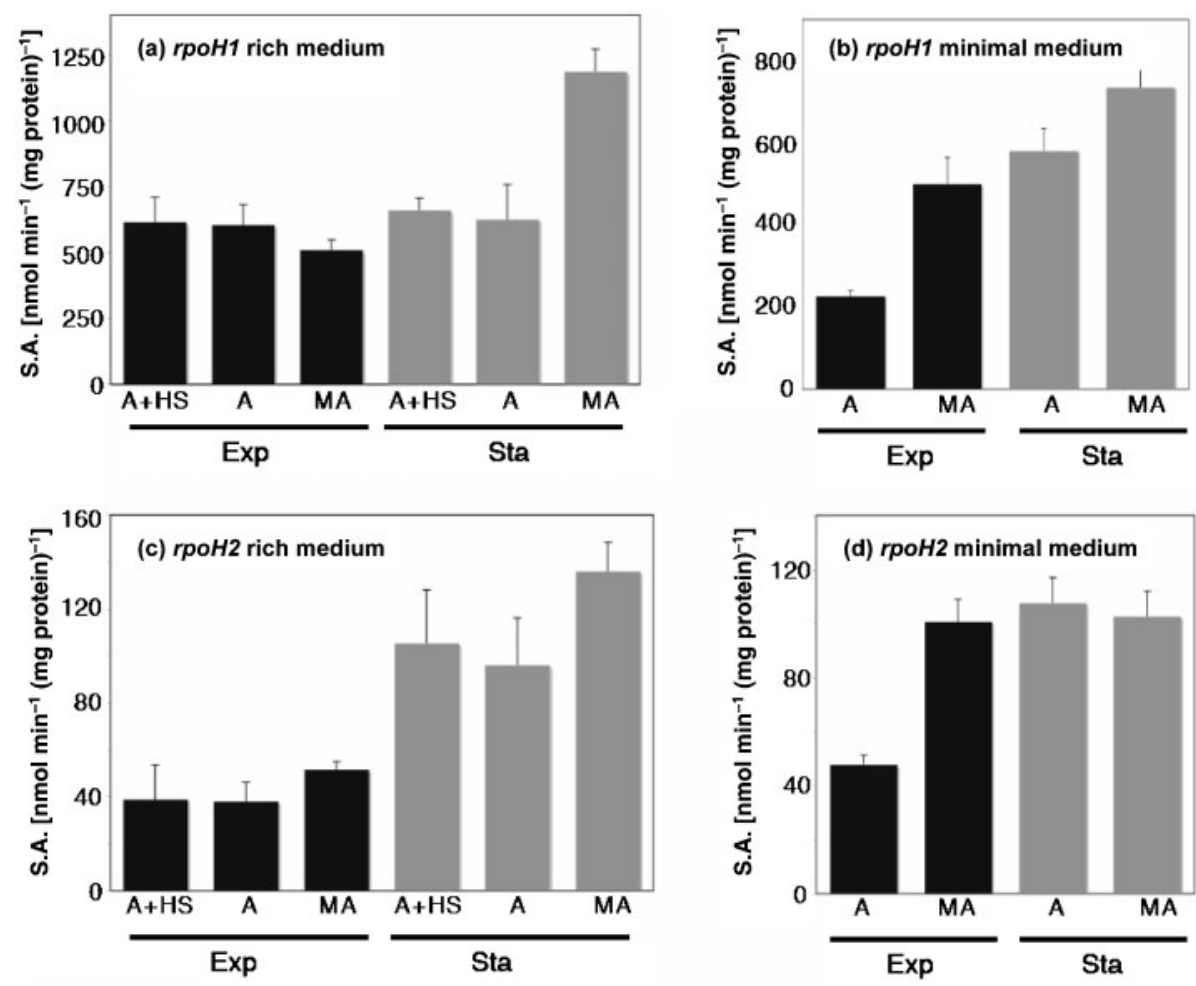

Fig. 6. Transcriptional expression of $\mathrm{R}$. etli $r p o H 1$ and $r p o H 2$ genes under different growth conditions. The expression on rich medium ( $a, c)$ or minimal medium (b, d) for rpoH1 (CE3/pGUSprpoH1) (a, b) and rpoH2 (CE3/pGUSprpoH2) (c, d) is shown. The gene expression in exponential (Exp) and stationary phases (Sta) is indicated by black and grey bars, respectively. A+HS, heat shock at $42{ }^{\circ} \mathrm{C}$ for 45 min of aerobic growth cultures; A, aerobic growth cultures; MA, microaerobic growth cultures. The data are the mean of at least three independent experiments. $\beta$-Glucuronidase specific activity [S.A.; $\mathrm{nmol} \mathrm{min}^{-1}$ ( $\mathrm{mg} \mathrm{protein)}^{-1}$ ] was determined.

capacity of $R$. etli to form nitrogen-fixing nodules in beans, the rpoH1-uidA fusion was expressed within the nodule. Twenty-one days after inoculation, the nodule exhibited a clear $\beta$-glucuronidase activity, indicating that the $r p o H 1$ gene was expressed during symbiosis. Similarly, at the same post-inoculation time, the rpoH2-uidA fusion was also expressed in nodules, but at lower levels than the rpoH1uidA fusion (data not shown).

\section{Analysis of $\mathrm{rpoH} 1$ and $\mathrm{rpoH} 2$ promoter regions}

To identify the probable promoters that control the expression of both $r p o H$ genes, the transcription start sites of these genes were determined. This was achieved by isolating total RNA from the wild-type $R$. etli under the following conditions: aerobic-exponential, aerobic-stationary, microaerobic-exponential, microaerobic-stationary, and after heat-shock stress ( $45 \mathrm{~min}$ at $\left.42{ }^{\circ} \mathrm{C}\right)$. Then, $5^{\prime}$ ends of mRNAs corresponding to rpoH1 and rpoH2 were identified by $5^{\prime}$ RACE. For $r p o H 1$, two RT-PCR products were obtained, one abundant under all tested conditions (Fig. 7a, S1) and a second less abundant product observed only at $42{ }^{\circ} \mathrm{C}$ (Fig. 7a, S2). The main transcription start site (S1), previously reported by Ramirez-Romero et al. (2006), (a)

AGGCGGCTTCGGGACACCGCTCTCGCCGCCTCACACCTGCGTGAGCGG CAdCTTGAACCGCGTTTCGCCATACIPATCTG CGGGCTI GGAACAAAGCCGCACGTCCOGGTT GGCGCGTTTCCATTGGGAGCCGGAATTCACTTTAGGAGGGTGCACT

(b)

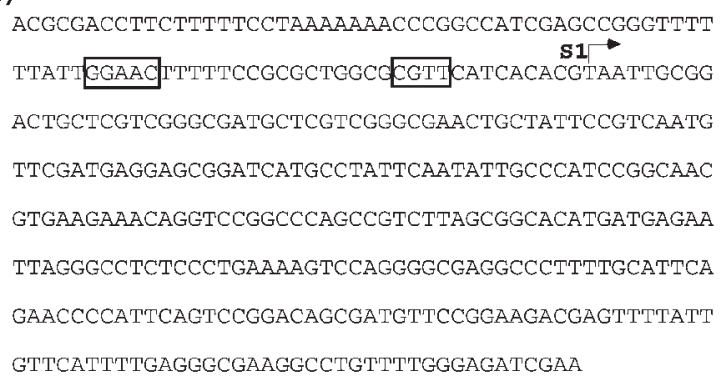

Fig. 7. Transcription start sites and putative promoters of $R$. etli rpoH1 (a) and rpoH2 (b) genes. Transcription start sites are marked with arrows and the letter $S$ above the nucleotide. The -10 and -35 elements are indicated by boxes. The probable promoters recognized by $\sigma^{70}(\mathrm{P} 1)$ and $\sigma^{\mathrm{E}}(\mathrm{P} 2)$ are delimited with lines. 
was located at an A nucleotide $101 \mathrm{bp}$ upstream of the translation start codon. Seven basepairs upstream of the transcription start site, an R. etli $\sigma^{70}$ promoter (CTTGAA$\mathrm{N}_{18}$-TATCTG; P1) was identified. The second putative transcription start site (S2) corresponded to an A nucleotide located $53 \mathrm{nt}$ upstream of the rpoH1 start codon. We did not find any evidence of an $R$. etli $\sigma^{70}$ promoter, but a sequence (GGAAC-N ${ }_{16}$-GGTT, P2) that is identical in eight out of nine positions to the $S$. meliloti RpoE2 consensus promoter (Sauviac et al., 2007) was situated at $8 \mathrm{bp}$ upstream of S2 (Fig. 7a). These results suggest that $\mathrm{rpoH} 1$ transcription is mainly controlled by $\sigma^{70}$, but transcripts could also be produced from the putative $\sigma^{\mathrm{E}}$ promoter at $42{ }^{\circ} \mathrm{C}$. The absence of induction of the rpoH1-uidA fusion after heat shock could be the result of a differential expression from these promoters.

For the $r p o H 2$ gene, three conspicuous RT-PCR products were obtained under all conditions tested. The putative transcription start sites corresponded to a $\mathrm{T}$ nucleotide (S1), a C nucleotide (S2) and a T nucleotide (S3), located 287, 100 and $36 \mathrm{nt}$ upstream of the gene, respectively. In this region the $R$. etli $\sigma^{70}$ promoter sequence was not found; however, 9 bp upstream of S1, a perfect match with the S. meliloti RpoE2 promoter consensus (GGAAC- $\mathrm{N}_{16^{-}}$ CGTT, P1) was identified, whereas for S2 and S3, no significant similarity to any promoter consensus was detected (Fig. 7b). The highest activity of $\mathrm{rpoH} 2$ being achieved in stationary phase and the presence of a putative $S$. meliloti RpoE2 promoter suggest control by the $\sigma^{\mathrm{E}}$ equivalent or another related sigma factor in $R$. etli.

\section{DISCUSSION}

In $\alpha$-proteobacteria genomes, it is common to find more than one $r p o H$ gene. The phylogenetic relationship among the entire set of RpoH proteins from $52 \alpha$-proteobacterium species showed two well separated clades. Proteins more similar to E. coli $\mathrm{RpoH}$ and close to the Rickettsiales clade constitute the first group. The second group includes all the alternative $\mathrm{RpoH} 2$ proteins (data not shown). It is not clearly understood how these additional $\mathrm{RpoH}$ proteins contribute to the heat-shock response and whether they have a role in other cellular processes. In this work, the RpoH-dependent stress responses of R. etli CE3 mediated by $r p o H 1$ and $r p o H 2$ genes, their expression, and the role of these genes in symbiosis with the common bean, $P$. vulgaris, were characterized. Both R. etli rpoH1 and rpoH2 were able to complement the sensitivity to heat of an E. coli $r p o H$ mutant, indicating that in E. coli both $\mathrm{R}$. etli rpoH genes encode elements necessary for the heat-shock response. Similar results have been obtained with other rpoH genes from several $\alpha$-proteobacteria (Delory et al., 2006; Green \& Donohue, 2006; Narberhaus et al., 1997; Oke et al., 2001; Ono et al., 2001).

R. etli rpoH null mutants were obtained by gene replacement at $25{ }^{\circ} \mathrm{C}$ in order to avoid suppressor mutations. Both rpoH1 and rpoH2 rpoH1 mutations compromised seriously the cell survival after heat shock. A similar behaviour was observed when the mutants were exposed to oxidative compounds such as $\mathrm{NaOCl}$ and $\mathrm{H}_{2} \mathrm{O}_{2}$. Also, in Brucella melitensis, an rpoH2 mutant was sensitive to oxidative stress (Delory et al., 2006). Considering that the $\mathrm{R}$. etli $r p o H 2 r p o H 1$ double mutant was even more sensitive to heat shock and oxidative agents than the rpoH1 single mutant, a synergistic effect might be necessary for a complete stress response. In contrast, the $R$. etli $\mathrm{RpoH} 2$ has a role in the tolerance to $\mathrm{NaCl}$ and sucrose without a clear participation of RpoH1. These results indicate a function for $\mathrm{RpoH} 2$ in the osmotic stress response. In S. meliloti strain 1021, an induction of $r p o H 2$ expression after osmotic stress has been reported (Domínguez-Ferreras et al., 2006), and in Sinorhizobium sp. strain BL3, an rpoH2 mutant is sensitive to salt stress (Tittabutr et al., 2006). Additionally, in Rhizobium sp. strain Tal1145, exopolysaccharide biosynthesis and expression of exo genes are RpoH2-dependent (Kaufusi et al., 2004). As a whole, these data suggest that in rhizobia, the $\mathrm{rpoH} 2$ gene is implicated in different stress responses, depending on the species.

In the present study we found that $R$. etli was more resistant to oxidative stress in the stationary phase than in the exponential phase. These results are in agreement with those described for E. coli and Rhizobium leguminosarum bv. phaseoli. These bacteria are more resistant to stress (oxidants, $\mathrm{pH}$, heat and osmotic shock) in the stationary phase than in the exponential growth phase (Díaz-Acosta et al., 2006; Ishihama, 1997; Nystrom, 2004; Thorne \& Williams, 1997). In E. coli, different mechanisms for stress resistance have been described; some of them are dependent on the stationary growth phase and on different sigma factors, $\sigma^{32}, \sigma^{\mathrm{E}}$ and $\sigma^{\mathrm{S}}$ (Bang et al., 2005).

In the soil, $R$. etli deals with many environmental variations that could induce physiological survival responses. In the nodule, Rhizobium also encounters an oxidizing environment. It has been shown that inactivation of genes related to oxidative stress in Rhizobium, such as katG (catalase), prxS (peroxiredoxin) and groELS (chaperones), affects the symbiotic process (Bittner \& Oke, 2006; Davies \& Walker, 2007; Dombrecht et al., 2005). It has been shown here that the $R$. etli rpoH2 mutant had a $\mathrm{Nod}+\mathrm{Fix}+$ phenotype, while rpoH1 and rpoH2 rpoH1 mutants were able to nodulate $P$. vulgaris plants, causing a Nod + Fix - phenotype. In addition, both rpoH1 and rpoH2 rpoH1 mutants showed a reduction in viable cell number in early and late nodulation states. Lack of nitrogen fixation could be a consequence of the poor bacterial growth inside the nodule. In addition, nodules formed by R. etli rpoH1 and rpoH2 rpoH1 mutants showed premature senescence. This phenotype resembles the one obtained with fix mutants, which also render nodules prematurely senescent (Brewin, 1991). The premature nodule senescence could be a consequence of the low capacity of the bacteria to respond to oxidative stress, 
although no satisfactory hypothesis has yet emerged. Looking for a connection between $\mathrm{RpoH}$ and nitrogen fixation, it was found that fixNf and fixKf expression was affected by rpoH1 inactivation. Accordingly, both rpoH1uidA and rpoH2-uidA fusions were expressed throughout the nodule, suggesting that $\mathrm{RpoH}$ proteins are involved in symbiosis. Consequently, it is proposed that both $\mathrm{RpoH}$ proteins are regulators that might connect the stress response with nitrogen fixation directly or indirectly; however, future experiments are needed to elucidate this function.

In $\mathrm{R}$. etli, the $\mathrm{rpoH} 1$ and $r p o H 2$ genes were expressed under all the conditions tested, and induced in the microaerobic stationary growth phase. Thus, the $\mathrm{R}$. etli $r p o H$ genes are induced by starvation and oxygen tension, which may be similar to the Rhizobium environment during nodule development. Moreover, rpoH1 was expressed at high levels in rich-medium aerobiosis; this could be due to the fact that aerobic metabolism generates molecules that cause oxidative stress as by-products. In contrast, $r p o H 1-u i d A$ and rpoH2-uidA expression was not affected after heat shock. In S. meliloti, similar results have been obtained in experiments with an rpoH1-uidA fusion (Oke et al., 2001). These results could be due to the existence of one or more transcriptional control elements.

In E. coli, $r p o H$ transcription is very sophisticated. There are five promoters upstream of the $r p o H$ gene, recognized by $\sigma^{70}(\mathrm{P} 1, \mathrm{P} 4$ and $\mathrm{P} 5), \sigma^{\mathrm{E}}(\mathrm{P} 3)$ and $\sigma^{54}$ (P6) (Erickson et al., 1987; Janaszak et al., 2007). In R. etli, upstream of the $r p o H 1$ gene, two promoter sequences have been identified. P1 is a strong promoter that resembles the -10 and -35 consensus boxes of the $R$. etli $\sigma^{70}$ promoter (RamírezRomero et al., 2006). Transcription from the $\mathrm{P} 2$ promoter was observed only in heat-shock stress. It has -10 and -35 boxes similar to the $S$. meliloti RpoE2 consensus promoter (Sauviac et al., 2007). In S. meliloti, RpoE2 is activated in stationary phase and after heat shock. Considering that $R$. etli rpoH1 transcription seems to be upregulated in microaerobic stationary phase, this expression is probably controlled by a $\sigma^{\mathrm{E}}$. Further experiments are needed to clarify which promoters are being used to transcribe $r p o H 1$, but the available evidence points to $\sigma^{70}$ as the main element of rpoH1 expression.

For the R. etli rpoH2 gene, three $5^{\prime}$ RACE products were detected. They allow for the identification of one (P1) probable promoter identical to the S. meliloti RpoE2 promoter consensus sequence (Sauviac et al., 2007). For the other putative transcription start sites, we were unable to detect sequences similar to known promoters. Recently, it has been reported that $S$. meliloti rpoH2 is expressed under the control of RpoE2 (Sauviac et al., 2007). Taking into consideration all data, we suggest that $\mathrm{R}$. etli $r p o H 2$ is regulated by $\sigma^{\mathrm{E}}$. Finally, based on our results, we propose that $\mathrm{RpoH} 1$ and $\mathrm{RpoH} 2$ are involved in different stress responses, and that this provides a major capacity to adapt to different environments.

\section{ACKNOWLEDGEMENTS}

We wish to thank Juan Pablo Fuentes, Ismael Hernández, José Luís Rodríguez, Patricia Bustos, Rosa Isela Santamaría, Guadalupe Zavala and José Espíritu for their skillful technical support. We also thank Paul Gaytán and Eugenio López for the synthesis of oligonucleotides. This work was supported by Consejo Nacional de Ciencia y Technologia (CONACyT) grants N-028, N-U46333-Q for emergent areas, IN220307 and IN201006 from Programa de Apoyo a Proyectos de Investigación e Innovación Technológica-Dirección General de Asuntos del Personal Académico (PAPIIT-DGAPA) Universidad Nacional Autónoma de México.

\section{REFERENCES}

Arsène, F., Tomoyasu, T. \& Bukau, B. (2000). The heat shock response of Escherichia coli. Int J Food Microbiol 55, 3-9.

Bang, I. S., Frye, J. G., McClelland, M., Velayudhan, J. \& Fang, F. C. (2005). Alternative sigma factor interactions in Salmonella: $\sigma^{\mathrm{E}}$ and $\sigma^{\mathrm{H}}$ promote antioxidant defences by enhancing $\sigma^{\mathrm{E}}$ levels. Mol Microbiol 56, 811-823.

Bittner, A. N. \& Oke, V. (2006). Multiple groESL operons are not key targets of RpoH1 and RpoH2 in Sinorhizobium meliloti. J Bacteriol 188, 3507-3515.

Botsford, J. L. \& Lewis, T. (1990). Osmoregulation in Rhizobium meliloti: production of glutamic acid in response to osmotic stress. Appl Environ Microbiol 56, 488-494.

Bravo, A. \& Mora, J. (1988). Ammonium assimilation in Rhizobium phaseoli by the glutamine synthetase-glutamate synthase pathway. J Bacteriol 170, 980-984.

Brewin, N. J. (1991). Development of the legume root nodule. Annu Rev Cell Biol 7, 191-226.

Davies, B. W. \& Walker, G. C. (2007). Identification of novel Sinorhizobium meliloti mutants compromised for oxidative stress protection and symbiosis. J Bacteriol 189, 2110-2113.

Delory, M., Hallez, R., Letesson, J. J. \& De Bolle, X. (2006). An RpoHlike heat shock sigma factor is involved in stress response and virulence in Brucella melitensis 16M. J Bacteriol 188, 7707-7710.

Díaz-Acosta, A., Sandoval, M. L., Delgado-Olivares, L. \& MembrilloHernandez, J. (2006). Effect of anaerobic and stationary phase growth conditions on the heat shock and oxidative stress responses in Escherichia coli K-12. Arch Microbiol 185, 429-438.

Ditta, G., Stanfield, S., Corbin, D. \& Helinski, D. R. (1980). Broad host range DNA cloning system for Gram-negative bacteria: construction of a gene bank of Rhizobium meliloti. Proc Natl Acad Sci U S A 77, 7347-7351.

Dombrecht, B., Heusdens, C., Beullens, S., Verreth, C., Mulkers, E., Proost, P., Vanderleyden, J. \& Michiels, J. (2005). Defence of Rhizobium etli bacteroids against oxidative stress involves a complexly regulated atypical 2-Cys peroxiredoxin. Mol Microbiol 55, 1207-1221.

Domínguez-Ferreras, A., Pérez-Arnedo, R., Becker, A., Olivares, J., Soto, M. J. \& Sanjuán, J. (2006). Transcriptome profiling reveals the importance of plasmid pSymB for osmoadaptation of Sinorhizobium meliloti. J Bacteriol 188, 7617-7625.

El-Samad, H., Kurata, H., Doyle, J. C., Gross, C. A. \& Khammash, M. (2005). Surviving heat shock: control strategies for robustness and performance. Proc Natl Acad Sci U S A 102, 2736-2741.

Erickson, J. W., Vaughn, V., Walter, W. A., Neidhardt, F. C. \& Gross, C. A. (1987). Regulation of the promoters and transcripts of $r p o H$, the Escherichia coli heat shock regulatory gene. Genes Dev 1, 419-432. 
Fahraeus, G. (1957). The infection of clover root hairs by nodule bacteria studied by a simple glass slide technique. J Gen Microbiol 16, 374-381.

Fischer, H. M. (1994). Genetic regulation of nitrogen fixation in rhizobia. Microbiol Rev 58, 352-386.

Galibert, F., Finan, T. M., Long, S. R., Puhler, A., Abola, P., Ampe, F., Barloy-Hubler, F., Barnett, M. J., Becker, A. \& other authors (2001). The composite genome of the legume symbiont Sinorhizobium meliloti. Science 293, 668-672.

Girard, L., Brom, S., Davalos, A., Lopez, O., Soberon, M. \& Romero, D. (2000). Differential regulation of fixN-reiterated genes in Rhizobium etli by a novel fixL-fixK cascade. Mol Plant Microbe Interact 13, 1283-1292.

Gonzalez, V., Santamaria, R. I., Bustos, P., Hernández-González, I., Medrano-Soto, A., Moreno-Hagelsieb, G., Janga, S. C., Ramírez, M. A., Jiménez-Jacinto, V. \& other authors (2006). The partitioned Rhizobium etli genome: genetic and metabolic redundancy in seven interacting replicons. Proc Natl Acad Sci U S A 103, 3834-3839.

Green, H. A. \& Donohue, T. J. (2006). Activity of Rhodobacter sphaeroides RpoHII, a second member of the heat shock sigma factor family. J Bacteriol 188, 5712-5721.

Gross, C. A. 1996. Function and regulation of the heat-shock proteins. In Escherichia coli and Salmonella: Cellular and Molecular Biology, 2nd edn, vol. 1, pp. 1382-1399. Edited by F. C. Neidhardt, R. Curtiss III, J. L. Ingraham, E. C. C. Lin, K. B. Low, B. Magasanik, W. S. Reznikoff, M. Rily, M. Schaechter \& H. E. Umbarger. Washington, DC: American Society for Microbiology.

Hanahan, D. (1983). Studies on transformation of Escherichia coli with plasmids. J Mol Biol 166, 557-580.

Ishihama, A. (1997). Adaptation of gene expression in stationary phase bacteria. Curr Opin Genet Dev 7, 582-588.

Janaszak, A., Majczak, W., Nadratowska, B., Szalewska-Palasz, A., Konopa, G. \& Taylor, A. (2007). A $\sigma^{54}$-dependent promoter in the regulatory region of the Escherichia coli rpoH gene. Microbiology 153, 111-123.

Kaneko, T., Nakamura, Y., Sato, S., Asamizu, E., Kato, T., Sasamoto, S., Watanabe, A., Idesawa, K., Ishikawa, A. \& other authors (2000). Complete genome structure of the nitrogen-fixing symbiotic bacterium Mesorhizobium loti (Supplement). DNA Res 7, 381-406.

Kaneko, T., Nakamura, Y., Sato, S., Minamisawa, K., Uchiumi, T., Sasamoto, S., Watanabe, A., Idesawa, K., Iriguchi, M. \& other authors (2002). Complete genomic sequence of nitrogen-fixing symbiotic bacterium Bradyrhizobium japonicum USDA110. DNA Res 9, 189-197.

Kaufusi, P. H., Forsberg, L. S., Tittabutr, P. \& Borthakur, D. (2004). Regulation of exopolysaccharide synthesis in Rhizobium sp. strain TAL1145 involves an alternative sigma factor gene, rpoH2. Microbiology 150, 3473-3482.

Keen, N. T., Tamaki, S., Kobayashi, D. \& Trollinger, D. (1988). Improved broad-host-range plasmids for DNA cloning in Gramnegative bacteria. Gene 70, 191-197.

Martínez-Salazar, J. M. \& Romero, D. (2000). Role of the $r u v B$ gene in homologous and homeologous recombination in Rhizobium etli. Gene 243, 125-131.

Metcalf, W. W. \& Wanner, B. L. (1993). Construction of new $\beta$ glucuronidase cassettes for making transcriptional fusions and their use with new methods for allele replacement. Gene 129, 17-25.

Mitsui, H., Sato, T., Sato, Y., Ito, N. \& Minamisawa, K. (2004). Sinorhizobium meliloti RpoH1 is required for effective nitrogen-fixing symbiosis with alfalfa. Mol Genet Genomics 271, 416-425.
Nakahigashi, K., Yanagi, H. \& Yura, T. (1995). Isolation and sequence analysis of $r p o H$ genes encoding $\sigma^{32}$ homologs from Gram negative bacteria: conserved mRNA and protein segments for heat shock regulation. Nucleic Acids Res 23, 4383-4390.

Narberhaus, F., Krummenacher, P., Fischer, H. M. \& Hennecke, H. (1997). Three disparately regulated genes for $\sigma^{32}$-like transcription factors in Bradyrhizobium japonicum. Mol Microbiol 24, 93-104.

Noel, K. D., Sanchez, A., Fernandez, L., Leemans, J. \& Cevallos, M. A. (1984). Rhizobium phaseoli symbiotic mutants with transposon Tn5 insertions. J Bacteriol 158, 148-155.

Nogales, J., Campos, R., BenAbdelkhalek, H., Olivares, J., Lluch, C. \& Sanjuan, J. (2002). Rhizobium tropici genes involved in free-living salt tolerance are required for the establishment of efficient nitrogenfixing symbiosis with Phaseolus vulgaris. Mol Plant Microbe Interact 15, 225-232.

Nonaka, G., Blankschien, M., Herman, C., Gross, C. A. \& Rhodius, V. A. (2006). Regulon and promoter analysis of the E. coli heat-shock factor, $\sigma^{32}$, reveals a multifaceted cellular response to heat stress. Genes Dev 20, 1776-1789.

Nystrom, T. (2004). Stationary-phase physiology. Annu Rev Microbiol 58, 161-181.

Oke, V., Rushing, B. G., Fisher, E. J., Moghadam-Tabrizi, M. \& Long, S. R. (2001). Identification of the heat-shock sigma factor RpoH and a second RpoH-like protein in Sinorhizobium meliloti. Microbiology 147, 2399-2408.

Ono, Y., Mitsui, H., Sato, T. \& Minamisawa, K. (2001). Two RpoH homologs responsible for the expression of heat shock protein genes in Sinorhizobium meliloti. Mol Gen Genet 264, 902-912.

Pichon, M., Journet, E. P., Dedieu, A., de Billy, F., Truchet, G. \& Barker, D. G. (1992). Rhizobium meliloti elicits transient expression of the early nodulin gene ENOD12 in the differentiating root epidermis of transgenic alfalfa. Plant Cell 4, 1199-1211.

Ramírez-Romero, M. A., Masulis, I., Cevallos, M. A., Gonzalez, V. \& Davila, G. (2006). The Rhizobium etli $\sigma^{70}$ (SigA) factor recognizes a lax consensus promoter. Nucleic Acids Res 34, 1470-1480.

Romero, D., Singleton, P. W., Segovia, L., Morett, E., Bohlool, B. B., Palacios, R. \& Davila, G. (1988). Effect of naturally occurring nif reiterations on symbiotic effectiveness in Rhizobium phaseoli. Appl Environ Microbiol 54, 848-850.

Sambrook, J., Fritsch, E. F. \& Maniatis, T. (1989). Molecular Cloning: a Laboratory Manual, 2nd edn. Cold Spring Harbor, NY: Cold Spring Harbor Laboratory.

Santos, R., Herouart, D., Sigaud, S., Touati, D. \& Puppo, A. (2001). Oxidative burst in alfalfa-Sinorhizobium meliloti symbiotic interaction. Mol Plant Microbe Interact 14, 86-89.

Sauviac, L., Philippe, H., Phok, K. \& Bruand, C. (2007). An extracytoplasmic function sigma factor acts as a general stress response regulator in Sinorhizobium meliloti. J Bacteriol 189, 42044216.

Schafer, A., Tauch, A., Jager, W., Kalinowski, J., Thierbach, G. \& Puhler, A. (1994). Small mobilizable multi-purpose cloning vectors derived from the Escherichia coli plasmids pK18 and pK19: selection of defined deletions in the chromosome of Corynebacterium glutamicum. Gene 145, 69-73.

Simon, R., Priefer, U. \& Puhler, A. (1983). A broad host range mobilization system for in vivo genetic engineering: transposon mutagenesis in Gram-negative bacteria. Biotechnology (N Y) 1, 784791.

Taylor, W. E., Straus, D. B., Grossman, A. D., Burton, Z. F., Gross, C. A. \& Burgess, R. R. (1984). Transcription from a heat-inducible promoter causes heat shock regulation of the sigma subunit of E. coli RNA polymerase. Cell 38, 371-381. 
Thorne, S. H. \& Williams, H. D. (1997). Adaptation to nutrient starvation in Rhizobium leguminosarum bv. phaseoli: analysis of survival, stress resistance, and changes in macromolecular synthesis during entry to and exit from stationary phase. J Bacteriol 179, 68946901.

Tittabutr, P., Payakapong, W., Teaumroong, N., Boonkerd, N., Singleton, P. W. \& Borthakur, D. (2006). The alternative sigma factor $\mathrm{RpoH} 2$ is required for salt tolerance in Sinorhizobium sp. strain BL3. Res Microbiol 157, 811-818.

Vento, R., Giuliano, M., Lauricella, M., Carabillo, M., Di Liberto, D. \& Tesoriere, G. (1998). Induction of programmed cell death in human retinoblastoma Y79 cells by C2-ceramide. Mol Cell Biochem 185, 7-15.
Wösten, M. M. (1998). Eubacterial sigma-factors. FEMS Microbiol Rev 22, 127-150.

Yamamori, T. \& Yura, T. (1980). Temperature-induced synthesis of specific proteins in Escherichia coli: evidence for transcriptional control. J Bacteriol 142, 843-851.

Yura, T., Nakahigashi, K. \& Kanemori, M. (1996). Transcriptional regulation of stress-inducible genes in procaryotes. EXS 77, 165-181.

Zahran, H. H. (1999). Rhizobium-legume symbiosis and nitrogen fixation under severe conditions and in an arid climate. Microbiol Mol Biol Rev 63, 968-989.

Edited by: H.-M. Fischer 